Apidologie, 1988, 19 (4), 343-354

\title{
COMB REPLACEMENT AND NOSEMA DISEASE (NOSEMA APIS Z.) IN HONEY BEE COLONIES
}

\author{
by \\ Ingemar FRIES \\ Bee Division \\ Swedish University of Agricultural Sciences \\ S-750 07 Uppsala (Sweden)
}

\begin{abstract}
SUMMARY
Honey bee colonies (Apis mellifera L.) were wintered for 5 successive years, on comb foundation, on brood nest wax changed early in the summer, or on the same combs throughout the experiment. It was shown that keeping bees on old comb increases the risk of detectable Nosema apis Z. spore levels in the spring and nosema disease was significantly correlated with winterloss. The spring peak of infection showed a significant positive correlation with the fall peak, only if severe fall infections were present, and the detrimental effect from nosema disease on honey yield was demonstrated. No important difference was seen among the experimental groups in honey yield or brood production in an analysis of linear models. The data show that early broodrearing increases, and nosema disease decreases the honey yield but only a slight negative effect from nosema on broodrearing was seen. Results indicate that early broodrearing increases disease level. The prospects in sanitary work of wintering on comb foundation should be further investigated.
\end{abstract}

\section{INTRODUCTION}

In Europe comb replacement in the brood nest of honey bee (Apis mellifera L.) colonies is generally regarded as an important sanitary measure (JORDAN, 1960 ; ZeCHA, 1964) and, therefore, is widely practiced. In contrast, combs in the USA are often used for decades before they are shifted out (KoENIG et al., 1986a, b). Old combs are durable during extraction and wax renewal involves labor. In addition, experimental results indicate more efficient storage of honey in dark combs (FreE \& Williams, 1972 ; Rinderer, 1980 ; RINDERER \& BAXTER, 1982) and drawing out comb foundation during the honeyflow reduces the honey yield (FrIES, 1981). However, there are many arguments in favor of comb replacement. Old combs in the supers also have a negative influence on honey quality (AlBer, 1974). Repeated use of the same 
combs in the brood nest results in smaller bees (JORDAN, 1960) and may allow microorganisms to accumulate (SMIRNov, 1982). It has been demonstrated that chalkbrood disease increases when old brood combs are used (KoENIG et al., 1986a, b).

BaIley $(1953,1954,1955 b)$ investigated old comb as a transmittor of Nosema apis between colonies, and concluded that soiled comb is the primary source of infection (BAILEY, 1953, 1981). BAILEY (1962) also demonstrated that viable spores can survive for at least one year in fecal deposits. To reduce the impact of nosema disease, it has been suggested that the early season is the most favorable part of the year to transfer bees to new combs (BaILeY, 1955b). However, Villumstad $(1969,1970,1980)$ described a successful wintering system developed partly for sanitary purposes, where the bees are put on comb foundation prior to winter feeding.

The hypothesis that soiled comb is the primary source of infection seems to be generally accepted, but only Bailey (1954), Villumstad (1969, 1970) and WeSSEL (1983) have studied the effect of different regimens of wax renewal on the infection level of $N$. apis infections.

The objectives of this study were to evaluate effects from different comb replacement schedules on nosema disease, brood production and honey yield.

\section{MATERIALS AND METHODS}

An apiary with 24 colonies was used for the experiment. The colonies were randomly divided into three groups of 8 colonies each. The groups were separated within the apiary to avoid drifting. During the experimental period of five years, group 1 was wintered on comb foundation as described by VILLUMSTAD (1970). In group 2, the brood nest wax was changed for virgin wax and comb foundations in early summer and the bees subsequently wintered on these combs. Group 3 received no wax renewal in the brood nest, and were wintered each year on the same combs. Group 1, 2 and 3 are also referred to as the 'foundation ', ' control' and 'old wax ' group or treatment respectively.

In another apiary, 12 colonies were divided into the same groups with 4 colonies in each. These colonies served as replacements with identical wax treatment for the appropriate number of years.

During the test, the colonies received approximately the same management, except for the wax treatment described, and were wintered each year in a single 10-frame hive body fitted with Swedish standard frames, $366 \times 222 \mathrm{~mm}$. During summer, the brood nest consisted of two 10-frame hive bodies.

All colonies included in the experiment were monitored for nosema spores twice a year. Collective samples of 60 live bees were taken from each hive cover as described by Fries et al. (1984). Spring samples were collected around the 15th of April, after the general cleansing flight, but before emerging bees appear in significant numbers in the colony. Fall samples were collected around the 15th of October, after winter feeding was completed and no brood normally is present in the hives.

The infection level was measured similar to CANTwell (1970), using hemacytometer counts, with $1 \mathrm{ml}$ water/bee, but counting 24 squares of $1 / 25 \mathrm{~mm}^{2}$ and diluting samples exceeding 15 spores/square, to facilitate the counting. The brood area of all colonies was calculated around May 15th, measuring the 
two axis of the brood ellipsis, similar to Fresnaye \& LensKy (1961). The honey production of each colony was measured throughout the experiment by weighing the supers before and after extraction.

The colonies were all fed $16 \mathrm{~kg}$ of sugar in syrup for the first winter. Two colonies in the foundation group died of starvation the first winter and were excluded from all calculations. Winterfeeding was increased to $19 \mathrm{~kg}$ of sugar in this group, for the remaining 4 years of the experiment.

Six colonies with queen failure, and another 10 colonies that died during winter, have not been included in the calculations concerning yield or brood, but data from nosema measurements on the live bees, are included if available.

The models used in the statistical analysis, were selected after removing insignificant covariance $(p>0.05)$ between independant variables. Continuous variables have been transformed to their relative value to reduce the influence of annual variations. The relative values are expressed as

$$
\frac{\text { observation for variable } X, \text { year } Y}{\text { arithmetic average of variable } X, \text { year } Y}
$$

\section{RESULTS}

Ten colonies died during the winter $(8.3 \%$ of total number of wintered colonies) and were replaced as described earlier. Of the ten colonies that died, seven had detectable levels of nosema disease, either in the fall or in the spring, the winter they died. The combination winterloss and nosema was found in 3 colonies in the foundation group, and in 2 colonies in each of the remaining groups. Hence, no difference between the groups in winterlosses related to nosema disease was detected. Considering all groups, nosema disease was significantly linked with winterloss $(p<0.05)$.

In Table 1 are shown $R^{2}$ and p-values from the analysis of linear models for each dependant variable analyzed.

Table 2 shows, in absolute numbers, the mean $(\bar{x})$ and the standard deviation (SD), for continous variables. A Ducan's test for differences between means, shows no significant effect from treatments.

\section{Nosema/spring}

The only dependent variable where wax treatment is shown to have an effect, is relative disease level in the spring $(p<0.001)$. The old wax group showed the highest relative infection, while the opposite was true for the foundation group.

The interaction between treatment and relative brood area, reflects a significant $(\mathrm{p}<0.001)$ negative relationship, between relative brood area and relative infection level, only for the old wax treatment (Table 1).

The model in Table 1 explains $17 \%$ of the variation in the spring disease level. No significant relationship $(p>0.05)$ between relative disease level in 


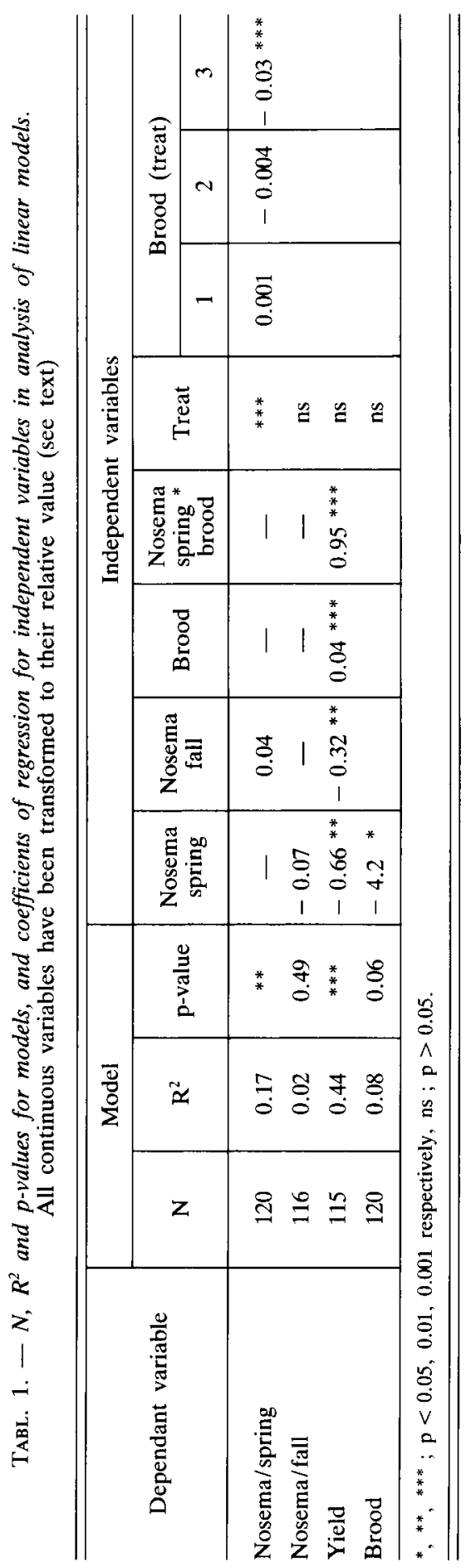


the fall, and relative disease level in the spring is shown. A simple analysis of correlation between these two variables however, shows a correlation coefficient, for these two variables, of $0.60(\mathrm{p}<0.001)$.

The mean spore count/bee, divided on year and treatment, can be seen in Fig. 1.

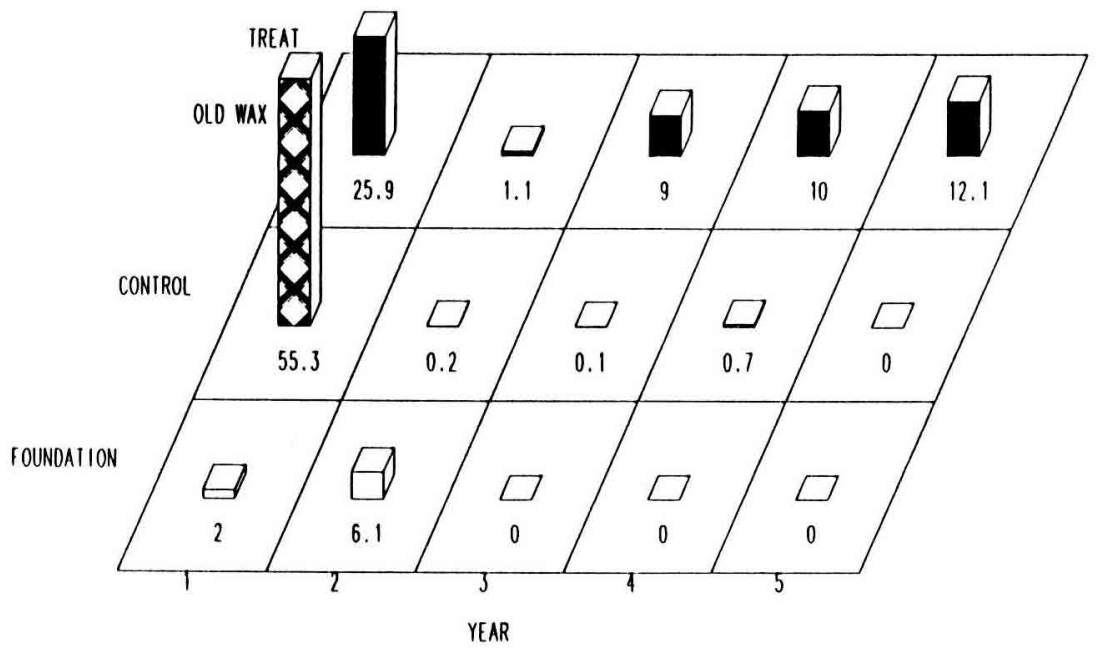

Fig. 1. - Mean $(\bar{x})$ infection levellcolony (spore count/bee $\left.\times 10^{5}\right)$, divided on year and treatment.

The total number of infected colonies in the spring in each group is seen in Fig. 2. An analysis of proportions shows, that compared to the foundation group, the old wax group had more colonies infected in the spring $(p<0.05)$.

\section{Nosemalfall}

The proportion of infected colonies in the fall did not differ significantly among the experimental groups $(p<0.05)$. Table 2 shows that, even though few infected colonies were found in the fall, the infection level tended to be higher in the old wax group.

\section{Honey yield}

The relative infection level in the spring $(\mathrm{p}<0.01)$, as well as the fall level $(\mathrm{p}<0.05)$, shows a negative influence on honey yield. Table 1 also demonstrates, that a large brood area in the spring significantly increases honey yield $(p<0.001)$. No important influence on yield was detected from 

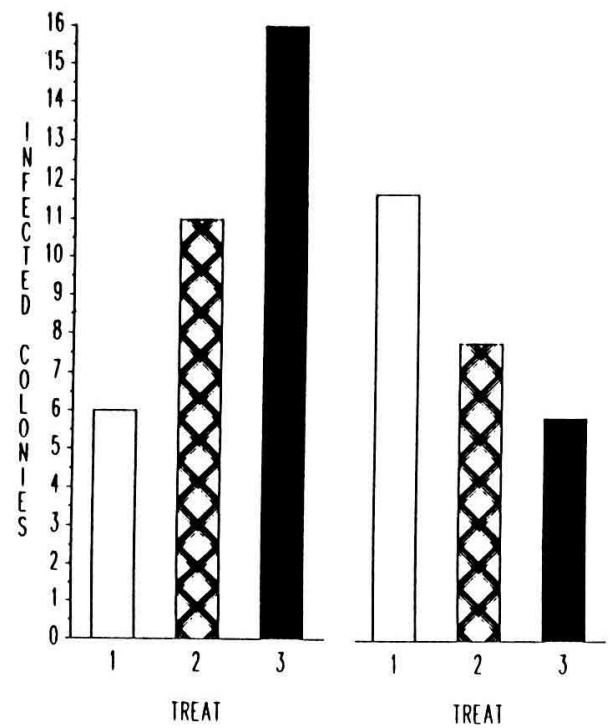

IREAT I = FOLNDAIION, TREAT $2=$ CONTROL, TREAI $3=$ OLD WAX

FIG. 2. - Number of infected colonies/treatment during five years in the spring and in the fall. $\mathrm{N}_{\text {spring }}=121, \mathrm{~N}_{\mathrm{fall}}=128$.

TABL. 2. - Five year mean \pm standard deviation $(\bar{x} \pm S D)$ for nosema disease level (spores/bee $\left.\times 10^{5}\right)$, broodarea $\left(\mathrm{cm}^{2}\right)$ and honey yield $(\mathrm{kg})$

\begin{tabular}{l|c|c|c}
\hline \hline \multirow{2}{*}{ Variable } & \multicolumn{3}{|c}{ Treat } \\
\cline { 2 - 4 } & $\begin{array}{c}\text { Foundation } \\
\overline{\mathrm{x}} \pm \mathrm{SD}\end{array}$ & $\begin{array}{c}\text { Control } \\
\overline{\mathrm{x}} \pm \text { SD }\end{array}$ & $\begin{array}{c}\text { Old wax } \\
\overline{\mathrm{x}} \pm \text { SD }\end{array}$ \\
\hline Nosema/spring & $1.6 \pm 4.9$ & $11.2 \pm 39.3$ & $11.9 \pm 38.4$ \\
Nosema/fall & $1.1 \pm 2.4$ & $0.8 \pm 2.4$ & $3.5 \pm 16.3$ \\
Broodarea & $4272.5 \pm 2271.9$ & $4678.7 \pm 2411.2$ & $4540.5 \pm 2473.6$ \\
Honey yield & $82.7 \pm 20.0$ & $79.8 \pm 24.2$ & $77.4 \pm 33.4$ \\
\hline
\end{tabular}

the different wax treatments. There is a significant interraction between disease level in the spring and brood area on honey yield in the model $(\mathrm{p}<0.001)$. The model in Table 1 explains $44 \%$ of the variation in honey yield over the 5 years examined. 


\section{Brood}

Only $8 \%$ of the variation in relative brood area, is explained by the model in Table 1. Nevertheless, increased disease level in the spring reduces the brood area $(p<0.05)$.

\section{DISCUSSION}

\section{Nosema/spring \& Nosemalfall}

It can be concluded that comb replacement reduces nosema disease level in honey bee colonies. The highest sporecounts/bee in a single colony in the spring $\left(2.3 \times 10^{7}\right)$, as well as in the fall $\left(1.0 \times 10^{7}\right)$, were found in the old wax group. Furthermore, compared to the foundation group, the old wax group exhibited an increased proportion of colonies with a detectable infection in the spring $(p<0.05)$. This corroborates the findings of BaILEY (1954), VillumSTAD, $(1969 ; 1970)$ and WESSEL (1983). However, some colonies with spring infections were then wintered on the same combs and exhibited no detectable nosema disease the following spring. This indicates that wax is only one factor among others that determine whether or not $N$. apis will influence the wintering capacity and productivity of honey bee colonies.

The significant correlation between nosema levels detected in the fall and the following spring, supports the statement of Furgala \& Mussen (1978) that the spring peak is dependent on the fall peak. However, the correlation rests on a few colonies, heavily infected in the fall which indicates that the correlation is also dependent on the magnitude of the fall peak. If a small number of bees are infected in the fall, other factors probably determine whether or not the presence of the parasite in the colony will cause a mass infection of the bees in the spring.

The largest number of colonies with detectable levels of nosema disease in the fall, was found in the foundation group (Fig. 2). The bees were shaken on to comb foundation approximately one month before examining the infection level in the fall. It is possible that the extra disturbance influenced the number of infected colonies in the fall. This eventual negative effect was not seen in the spring, since no spring infection was detected in the foundation group, for the last 3 years of the experiment. 
Honey yield

The effect of nosema disease on honey yield was found to corroborate the findings of other authors (Farrar, 1947 ; Hammer \& Karmo, 1947 ; Moeller, 1962 ; L'Arrivée, 1966 ; Cantwell \& Shimanuki, 1969 ; Fries et al., 1984). The significant interaction between nosema levels in the spring and brood production, suggests that the impact of the disease on productivity is not a simple linear relationship. The effect of a certain degree of infection in the spring, probably depends on annual climatic variations, and on the broodrearing intensity at that time.

High infection levels in spring, as well as a small brood area, is shown to decrease the honey yield. Nevertheless, the regression coefficient for the interaction between these two variables on honey yield is positive. One possible hypothesis is that early and intensive broodrearing is an exertion that increases the risk of spreading nosema within the colony, through feces deposited on the wax, when the bees have only limited flight possibilities. The raised temperature in the brood nest also contributes to the rate of development of the parasite (Lotmar, 1943). If the disease does not reach critical levels, however, the increased brood production will overcome the negative effects of the disease, since emerging bees are nosema free (BAILEY, 1955c). The available data does not allow conclusions on the magnitude of this critical level, but it probably will vary, with the climatic conditions and sampling time.

\section{Brood}

Although the model for brood in Table 1 does not reach significance $(p=0.06)$, the analysis shows a negative influence from nosema infection in the spring, on the brood development. A negative effect on brood rearing probably exists in heavily infected colonies, as demonstrated by FARRAR (1947), but weaker infections are less likely to conflict with the colonies' ability to produce sufficient amount of larval food. Thus, brood development is not a « nosema disease barometer », as suggested by STECHE (1969).

\section{General}

The complex of factors that affects nosema disease in honey bee colonies under field conditions, is still poorly understood. The present investigation supports the findings of BAILEY (1953, 1954, 1955b), that old comb contributes to nosema disease. On the other hand, it is also evident that combs from infected colonies, even when stained with feces, do not necessarily transmit detectable levels of the disease from one season to the next. Data suggest that broodrearing contributes to the spread of the disease in the spring. This supports the hypothesis of BAILEY (1955a), where spores are ingested by the 
bees as they clean combs for the expanding brood nest. Thus, the timing of early brood rearing, in relation to infection level and flight possibilities, probably is important for the course of development of the disease.

The influence of $N$. apis on the honey yield is only partly explained by reduced brood rearing capacity due to the parasite. The lifespan of infected bees is shortened (Beutler \& Opfinger, 1949) and the winter loss from the cluster increases in infected colonies (JEFFREE \& ALLEN, 1956). Factors correlated with dysentery could also inhibit colony growth in spring (BAILEY, 1967) and the impact of the disease is probably influenced by eventual secondary infections (BAILEY, 1982).

BAILEY (1955b) suggested that, for sanitary reasons, bees should be transferred to new comb in the early season. The present results do not support this suggestion. No differences were found between the experimental groups in broodrearing or honey yield over the whole period, and the lowest amount of nosema infection was found in the foundation group. Thus, to transfer bees to comb foundation in the fall is an interesting possibility. The foundation group was wintered around the 15th of September and very little, if any, pollen foraging was possible before winter. With early pollen available in the spring, as in this experiment, possible negative effects on early broodrearing were undetected.

It can be concluded that wintering bees on comb foundation, after the brood rearing period is over, is possible if sufficient amounts of sugar are supplied. Wintering on comb foundation reduces the influence of nosema disease compared to the use of old combs in the brood nest. The prospects in sanitary work of wintering on comb foundation, especially concerning brood diseases, should be investigated.

Received for publication in October 1987. Accepted for publication in July 1988.

\section{ACKNOWLEDGEMENTS}

The author wishes to thank Prof. J. Pettersson and Prof. E. Villumstad for helpful criticism of the manuscript. A special thank is due to Dr. G. Ekbohm for valuable suggestions on the statistical analysis. The project had financial support from the Swedish Board of Agriculture. 


\section{RÉSUMÉ \\ RENOUVELLEMENT DES RAYONS ET NOSÉMOSE (NOSEMA APIS ZANDER) DANS LES COLONIES D'ABEILLES}

On a fait hiverné durant 5 années successives des colonies d'abeilles (Apis mellifica L.) par groupes de 8 , sur des feuilles de cire gaufrée, sur la cire du nid à couvain renouvelée chaque été ou sur les mêmes rayons durant toute l'expérience. On a montré que le fait de maintenir les abeilles sur de vieux rayons accroît le risque de détecter au printemps des teneurs en spores de Nosema apis $\mathrm{Z} .(\mathrm{p}<0,05)$ (Figs. 1 et 2). La nosémose est significativement corrélée avec les pertes hivernales $(p<0,05)$. Le maximum printanier d'infection est positivement et significativement corrélé avec le minimum automnal, seulement s'il existe une infection importante à l'automne et si l'on a pu montré un effet négatif de la nosémose sur la production de miel (Tabl. 1).

Le plus grand nombre de spores par abeille a été trouvé dans le groupe sur la vieille cire, que ce soit au printemps $\left(2,3 \times 10^{7}\right)$ ou à l'automne $\left(1,0 \times 10^{7}\right)$. Ce groupe a aussi le plus grand nombre moyen de spores (Tabl. 2), bien que les différences entre les groupes ne soient pas significatives ( $p>0,05$ ). Dans le groupe sur cire gaufrée, on n'a trouvé aucune colonie infectée au printemps durant les 3 dernières années de l'expérience, mais ce groupe a eu besoin de plus de sucre pour hiverner que les autres.

Une analyse des modèles linéaires montre que l'élevage du couvain a une influence positive $(\mathrm{p}<0,001)$ et la nosémose une influence négative $(\mathrm{p}<0,05)$ sur la production de miel. La nosémose n'a que peu d'effet sur l'élevage du couvain. Les résultats indiquent que l'élevage précoce du couvain augmente le niveau de la maladie. On n'a pas vu de différence importante entre les groupes expérimentaux vis-à-vis de la production de miel et celle de couvain.

\section{ZUSAMMENFASSUNG \\ WABENAUSTAUSCH UND NOSEMATOSE (NOSEMA APIS Z.) BEI VÖLKERN DER HONIGBIENE}

Völker der Honigbiene (Apis mellifera L.) wurden in fünf aufeinanderfolgenden Jahren in Gruppen zu je 8 überwintert :

- auf Mittelwänden,

- auf Brutwaben, die im frühen Sommer ausgetauscht wurden oder

— auf den gleichen Waben während des ganzen Versuchs.

Es konnte gezeigt werden, daß bei den Bienen, die auf alten Waben gehalten werden, das Risiko, im Frühjahr einen nachweisbaren Nosema apis-Sporenlevel aufzuweisen, ansteigt ( $p<0.05$ ) (Abb. 1 und 2). Außerdem war die Nosematose signifikant korreliert mit den Winterverlusten $(p<0.05)$. Der Frühjahrsgipfel der Infektion zeigte nur im Falle einer sehr ernsthaften Herbstinfektion eine signifikant positive Korrelation mit dem Herbstpeak. Außerdem konnte ein nachteiliger Effekt der Nosematose auf die Honingproduktion nachgewiesen werden (Tab. 1). Die höchsten Sporenzahlen/Biene im Frühling $\left(2.3 \times 10^{7}\right)$ und im Herbst $\left(1.0 \times 10^{7}\right)$ wurden in der Gruppe mit den alten Waben gefunden. Die Altwabengruppe hatte außerdem die größte mittlere Sporenzahl (Tab. 2) allerdings waren die Differenzen zwischen den Gruppen nicht signifikant ( $p>0.05$ ). In der Gruppe mit Mittelwänden wurden in den letzten drei Jahren des Versuchs im Frühjahr keine infizierten Völker gefunden, jedoch verbrauchte die Mittelwändegruppe mehr Zucker im Winter als die anderen Gruppen.

Eine Analyse von linearen Modellen ergab, daß Brutaufzucht einen positiven $(p<0.001)$ und Nosematose einen negativen Einfluß $(p<0.05)$ auf den Honigertrag hat. Nosematose hat nur einen geringen Effekt auf die Brutaufzucht. Die Ergebnisse lassen darauf schließen, daß frühe Brutaufzucht den Krankheitsgrad erhöht. In den Versuchsvölkern sind keine großen Unterschiede im Honigertrag und in der Brutproduktion aufgetreten. 


\section{REFERENCES}

Alber M.A., 1974. - Light and dark honey - from white and brown combs. Am Bee J., $114,373$.

Bailey L., 1953. - The transmission of nosema disease. Bee World, 34, 171-172.

Bailey L., 1954. - The control of Nosema disease. Bee World, 35, 111-113.

Balley L., 1955a. - The epidemiology and control of nosema disease of the honeybee. Ann. appl. Biol., 43, 379-389.

BAILEY L., 1955b. - Results of field trials at Rothamsted of control methods for nosema disease. Bee World, 36, 121-125.

Balley L., 1955c. - The infection of the ventriculus of the adult honeybee by Nosema apis (Zander). Parasitology, 45, 86-94.

Bailey L., 1962. - Rep. Rothamsted Exp. St. 1961, 160-161.

BaILeY L., 1967. - Nosema apis and dysenteria of the honeybee. J. apic. Res., 6, 121-125.

Bailey L., 1981. - Honey Bee Pathology. London : Acad. Press.

BAILEY L., 1982. - Viruses of honeybees. Bee World, 63, 165-173.

Beutler R., Opfinger E., 1949. - Pollenernährung und Nosemabefall der Honigbiene. $Z$. vergl. Physiol., 32, 383-421.

Cantwell G.E., 1970. - Standard methods for counting nosema spores. Am. Bee J., 110, $222-223$.

Cantwell G.E., Shimanuki H., 1969. - Heat treatment as a means of eliminating nosema and increasing production. Am. Bee J., 109, 52-54.

FARRar C.L., 1947. - Nosema losses in package bees as related to queen supersedure and honey yields. J. econ. Entomol., 490, 333-338.

Free J.B., Williams I.H., 1972. - Hoarding by honeybees (Apis mellifera L.). Anim. Behav., 20, 327334.

Fresnaye J., LenSKY Y., 1961. - Méthodes d'appréciation des surfaces de couvain dans les colonies d'abeilles. Ann. Abeille, 4, 369-376.

FrIES I., 1981. - The influence of comb building before and during the main honeyflow on the swarmtendency and honey yield of honey bee colonies. Am. Bee J., 121, 651-652, 655-656.

Fries I., Еквонм G., Villumstad E., 1984. - Nosema apis, sampling techniques and honey yield. $J$. apic. Res., 23, 102-105.

Furgala B., Mussen E.C., 1978. - Protozoa. In Honey Bee Pests Predators and Diseases. Ed. Morse, R. London: Cornell Univ. Press, 63-77.

Hammer O., Karmo E., 1947. - Nosema und Honigertrag. Schweiz. Bienenztg., 70, 190-194.

Jeffree E.P., Allen M.D., 1956. - The influence of colony size and of Nosema disease on the rate of population loss in winter. J. econ. Entomol., 49, 831-834.

JoRDAN R., 1960. - Die Bedeutung der Bauerneuerung für die Leistungfähigkeit der Bienenvölker. Bienenvater, 81, 101-105.

Koenig J.P., Boush G.M., Erickson E.H., Jr, 1986a. - Effect of type of brood comb on chalkbrood disease in honey bee colonies. $J$. apic Res., 25, 58-62.

Koenig J.P., Boush G.M., ERIckson E.H., 1986b. - Old comb may contribute to chalkbrood disease. Am. Bee J., 126, 191-192.

Lotmar R., 1943. - Über den Einfluss der Temperatur auf den Parasiten Nosema apis. Beih. Schweiz. Bienenztg., 1, 261-284.

L'Arrivée J.C.M., 1966. - Effets de la nosémose sur le rendement en miel. Can. Agric., 11, $24-25$.

Moeller F.E., 1962. - Nosema disease control in package bees. Am. Bee J., 109, 390-392.

Rinderer T.E., 1980. - Hoarding behaviour of the honey bee : Effect of empty comb, comb color and genotype. Environ. Entomol., 9, 104-105.

Rinderer T.E., Baxter J.R., 1982. - Amount of empty comb, comb color and honey production. Am. Bee J., 120, 641-642. 
Smirnov A.M., 1982. - Study of microbial contamination of hives and combs, and methods of disinfection. Apiacta, 17, 100-104, 119.

STECHE W., 1969. - Relationships between the development of the parasite Nosema apis (Zander) and the brood development of bees. In Proc. XXIInd Int. Beekeep. Cong. Munich 1969. Apimondia Publ. House, Bucharest, 583-585.

Villumstad E., 1969. - Wintering and spring development of colonies on combs drawn out during autumn feeding. In Proc. XXIInd Int. Beekeep. Cong. Munich 1969. Apimondia Publ. House, Bucharest, 605-608.

Villumstad E., 1970. - Overvintring og vårutvikling av bifolk på tavler som ble bygget ut under høstforinga. Birøkteren, 86, 36-43.

Villumstad E., 1980. - Eine Methode zur Nosema-Prophylaxe aus Norwegen. Allg. Dtsch. Imkerztg., 14, 38-40.

Wessel F., 1983. - Nosematose bei der Honigbiene Apis mellifica. Untersuchungen über Möglichkeiten der Prophylaxe - derzeitiger Stand der Nosema-Forschung. Inaug. Diss., Tierärztliche Hochschule, Hannover, FRG, 108 p.

ZесHA H., 1964. - Bauererneuerung im Dienste der Gesundhaltung und Leistungs-Steigerung unserer Bienenvölker. Bienenvater, 85, 185-190, 267-272. 